\title{
Natural Killer Cell Activity in Adolescents With Major Depression
}

\author{
Benjamin N. Shain, Ziad Kronfol, Michael Naylor, Kavita Goel, \\ Tamlynn Evans, and Sara Schaefer
}

\section{Introduction}

An increasingly large body of work in adults has shown that derangements in the immune system, a critical protector from disease, are associated with stress, bereavement, and depression (for review, see Schleifer et al 1986, Calabrese et al 1987). We (Kronfol et al 1989) and others (Mohl et al 1987; Nerozzi et al 1989; Irwin et al 1990) have reported lower natural killer (NK) cell activity, a parameter of immune function directed against virus-infected or tumor cells (Herberman and Ortaido 1981), in adults with major depression. Other investigators, however, found no difference in NK cell activity between depressed adults and controls (Schleifer et al 1989). The current study compares NK cell activity in depressed adolescent inpatients and age- and sex-matched normal controls.

\section{Methods}

\section{Subjects}

Subjects were 16 psychiatry inpatients and 16 age- and sex-matched normal controls. Six subjects in each group were male and ten were

Fron the Department of Psychiatry, University of Michigan, Ann Arbor, MI.

Address reprint requesis to Benjamin N. Shain, M.D., Ph.D., Charter Hospital of Toledo, 1725 Timber Line Road, Maumee, OH 43537. Received February 15, 1990; revised July 31, 1990.

Presented at the annual meeting of the Society of Biological Psychiatry, May, 1990. female. There was no significant age difference between the patients ( $15.8 \pm 1.5$ years $)$ and the controls $(15.8 \pm 1.2$ years $)(t=0.06, p=$ NS) (age range for both: 13-18 years). Written informed consent was obtained (subjects and parents). Patients were Tanner Stage III or above; pubertal status of controls was not assessed formally, bui all appeared to be postpubertal. Patients were diagnosed as having primar. ma or depressive disorcier - rding to Researchì $\mathrm{Di}$ agnostic Criteria, usiag informaticn from a mu: tidisciplinary assessment and an interview with the Schedule for Affective Disorders and Schizophrenia, Present Episode version (SADS) (Endicott and Spitzer 1978), by a child psychiatrist. Interrater reliability for depression diagnoses using the SADS was $k=0.83$ for interviews that included an observer. Eleven patients had the endogenous subtype. Severity of depressive symptoms was measured with the selfreport Reynolds Adolescent Depression Scale (RADS) (Reynolds and Coats 1986) and the clinician-rated Children's Depression Rating ScaleRevised (CDRS-R) (Poznanski et al 1984).

Normal conirols were paid, healthy volunteers recruited through advertisements. Volunteers were screened for any past or present psychiatric disorders, and were assessed for current depressive symptoms with the RADS and CDRS-R.

Exclusionary criteria for all subjects included: medical disorder, including any infection; the use of psychotropic medications, street 
drugs, or medication known to affect the immune system any time during the 2 weeks prior to the assay, substance use disorder, cigarette use in the 2 weeks prior to the assay, and weight less than $85 \%$ of ideal. In addition, patients were excluded if their depressive symptoms remitted in an initial 2-3 week medication-free observation period. Substance use was ruled out by history in the controls and by history and an admission urine drug screen in patients.

\section{Assay}

Fresh blood samples from each patient and his or her control were assayed for NK cell activity on the same day to control for day-to-day variance in the assay. Lymphocytes were separated and monocytes depleted as described previously (Kronfol et al 1989). Percent cytotoxicity was calculated for each of four effector-to-target cell (E:T) ratios, 50:1, 25:1, 12.5:1, and 6.25:1, in a 4-hr ${ }^{51} \mathrm{Cr}$-release cytotoxicity assay with human erythroleukemia cell line K562 as target cells (Nair and Schwartz 1984). All samples were run in triplicate.

\section{Results}

Highly significant differences in depressive symptoms were found between the patients and controls using the RADS $(85.5 \pm 16.8$ versus $45.5 \pm 10.3, t=9.02, p<0.0001)$ and the CDRS-R $(62.6 \pm 11.8$ versus $19.5 \pm 1.1, t$ $=12.4, p<0.0001)$. There was no significant difference in NK cell activity, however, between patients and matched controls at any E:T ratio (Table 1). Furthermore, to assess the overall difference between the groups, we used repeated-measures analysis of variance (ANOVA) of NK cell activity. There was a highly significant E:T ratio effect $(F=240.3, d f=3, p<$ $0.0001)$, but no significant group effect $(F=$ $0.4, d f=1, p=N S$ ) or group by $\mathrm{E}: \mathrm{T}$ ratio interaction ( $F=0.1, d f=3, p=\mathrm{NS})$.

We did, however, find significant correlations between age and NK cell activity in both patients and controls (Table 2). Perhaps more importantly, we also found significant negative
Table 1. Natural Killer Cell Activity in Depressed Patients and Matched Controls

\begin{tabular}{|c|c|c|c|c|}
\hline & $\begin{array}{l}\text { Patients } \\
(n=16)\end{array}$ & $\begin{array}{l}\text { Controls } \\
(n=16)\end{array}$ & & \\
\hline $\begin{array}{l}\text { E:T } \\
\text { ratio }\end{array}$ & $\begin{array}{c}\text { Percent } \\
\text { cytotoxicity }\end{array}$ & $\begin{array}{l}\text { Percent } \\
\text { cytotoxicity }\end{array}$ & Paired $\mathrm{f}$ & $\boldsymbol{p}$ \\
\hline $50: 1$ & $63.9 \pm 15.1$ & $66.9 \pm 15.4$ & 1.00 & NS \\
\hline 25:1 & $51.1 \pm 15.5$ & $53.9 \pm 16.6$ & 0.66 & NS \\
\hline 12.5:1 & $32.9 \pm 13.6$ & $36.1 \pm 15.5$ & 0.74 & NS \\
\hline $6.25: 1$ & $18.5 \pm 10.3$ & $20.2 \pm 11.7$ & 0.55 & NS \\
\hline
\end{tabular}

-Control subjects matched for age and sex and assayed on the same day.

'Specific ${ }^{s !} \mathrm{Cr}$ release: mean \pm standard deviation.

'Paired t-test, two-tailed.

correlations between scores on the RADS and patient NK cell activity at 25:1 and 12.5:1 E:T ratios (Table 3). A trend toward significance was found for correlations between scores on the RADS and NK cell activity at 50:1 and 6.25:1 E:T ratios, and between scores on the CDRS-R and NK cell activity at $25: 1$ and 12.5:1 E:T ratios. The possible depression effect on NK cell activity appeared to be unaffected by age, however. Age did not significantly correlate with scores on the RADS ( $r=0.07, p=N S)$ or the CDRS-R $(r=0.14, p=N S)$ in the patient group. In addition, correlations between NK cell activity and scores on the RADS and CDRS-R were very similar to the respective partial correlations which took out the effect of age (Table 3).

Table 2. Correlation Between Natural Killer Cell Activity and Age

\begin{tabular}{cccccc}
\hline & \multicolumn{2}{c}{$\begin{array}{c}\text { Patients } \\
(n=16)\end{array}$} & & \multicolumn{2}{c}{$\begin{array}{c}\text { Controls } \\
(n=16)\end{array}$} \\
\cline { 2 - 3 } \cline { 5 - 6 } E:T ratio & $r$ & $p<$ & & $r$ & $p<$ \\
\hline $50: 1$ & 0.52 & 0.05 & & 0.76 & 0.001 \\
$25: 1$ & 0.57 & 0.05 & & 0.64 & 0.01 \\
$12.5: 1$ & 0.55 & 0.05 & & 0.49 & 0.10 \\
$6.25: 1$ & 0.55 & 0.05 & & 0.44 & 0.10 \\
\hline
\end{tabular}


Table 3. Correlation Between Natural Killer Cell Activity and Severity of Depression in Depressed Patients $^{a}$

\begin{tabular}{|c|c|c|c|c|c|c|c|c|}
\hline \multirow[b]{3}{*}{ E:T ratio } & \multicolumn{4}{|c|}{ RADS $^{b}$} & \multicolumn{4}{|c|}{ CDRS-R } \\
\hline & \multicolumn{2}{|c|}{ Correlation } & \multicolumn{2}{|c|}{$\begin{array}{c}\text { Partial } \\
\text { correlation }\end{array}$} & \multicolumn{2}{|c|}{ Correlation } & \multicolumn{2}{|c|}{$\begin{array}{c}\text { Partial } \\
\text { correlation }^{d}\end{array}$} \\
\hline & $r$ & $p<$ & $r$ & $p<$ & $r$ & $p<$ & $r$ & $p<$ \\
\hline $50: 1$ & -0.46 & 0.10 & -0.50 & 0.10 & -0.36 & NS & -0.24 & NS \\
\hline 25:1 & -0.58 & 0.05 & -0.66 & 0.01 & -0.44 & 0.10 & -0.37 & NS \\
\hline 12.5:1 & -0.57 & 0.05 & -0.64 & 0.05 & -0.48 & 0.10 & -0.47 & 0.10 \\
\hline $6.25: 1$ & -0.46 & 0.10 & -0.47 & 0.10 & -0.38 & NS & -0.39 & NS \\
\hline
\end{tabular}

$a_{n}=16$.

${ }^{b}$ Reynolds Adolescent Depression Scale.

'Children's Depression Rating Scale-Revised.

Correlation after partialing cut the effect of age.

\section{Discussion}

To our knowledge this is the first report of NK cell activity in depressed adolescents. No significant differences were found between patients and matched controls in paired and group comparisons. These findings are in contrast to findings of significantly lower NK cell activity in depressed adults previously reported by our group (Kronfol et al 1989) and others (Mohl et al 1987; Nerozzi et al 1989; Irwin et al 1990). They do, however, support work by other investigators (Schleifer et al 1989), who found no overall difference in NK cell activity between depressed adults and controls. These inconsistencies in findings suggest that there are unknown factors that affect the association between NK cell suppression and depressive illness.

Age effects on NK cell activity is controversial (Horikoshi 1985). In the current study, age significantly correlated with NK cell activity. Age, however, did not appear to be one of the factors affecting the association between NK cell suppression and depressive symptomatology, at least within the adolescent age range.

The current study found significant negative correlations between patient NK cell activity at two E:T ratios and scores on the RADS, and a trend toward significant negative correlations with scores on the CDRS-R. Severity of depression may be a factor in NK cell activity in depressed adolescents. Work is currently underway to clarify whether clinical and neuroendocrine factors are associated with lower NK cell activity in depressed patients.

This work was supported in part by NIMH Grant MH42988. We thank Elizabeth Hill, Ph.D., for her help with the statistical analysis.

\section{References}

Calabrese JR, Kling MA, Gold PW (1987): Alterations in immunocompetence during stress, bereavement, and depression: Focus on neuroendocrine regulation. Am J Psychiatry 114:11231134.

Endicott J, Spitzer RL (1978): A diagnostic interview. The Schedule for Affective Disorders and Schizophrenia. Arch Gen Psychiatry 35:837-844.

Herberman, RB, Ortaldo JR (1981): Natural killer cells: Their role in defenses against disease. Science 214:24-30.

Horikoshi T (1985): Significant differences in natural killer cell activity in chilaren according to age and sex. Kurume Med J 32:63-69.

Irwin M, Patterson T, Smith TL, et al (1990): Reduction of immune function in life stress and depression. Biol Psychiatry 27:22-30.

Kronfol Z, Nair M, Goodson J, Goel K, Haskett R, Schwartz S (1989): Natural killer cell activity in depressive illness: A preliminary report. Biol Psychiatry 26:753-756.

Mohl PC, Huang L, Bowden C, Fischbach M, Vogts- 
berger $K$. Talal $\mathbf{N}$ (1987): Natural killer cell activity in major depression. Am $J$ Psychiatry 144:1619.

Nair MPN, Schwartz SA (1984): Immunomodulatory effects of corticosteroids on natural killer and antibody-dependent cellular cytotoxic activities on human lymphocytes. J Immunol 132:2876-2882.

Nerozzi D, Santoni A, Bersani G, et al (1989): Reduced natural killer cell activity in major depression: Neuroendocrine implications. Psychoneuroendocrinology 14:295-301.

Poznanski EO, Grossman JA, Buchsbaum Y, Banegas M. Freeman L, Gibbons R (1984): Prelim- inary studies of the reliability and validity of the Children's Depression Rating Scale. J Am Acad Child Psychiatry 23:191-197.

Reynolds WM, Coats KI (1986): A comparison of cognitive-behavioral therapy and relaxation training for the treatment of depression in adolescents. $J$ Consult Clin Psychol 54:653-660.

Schleifer SJ, Scott B, Stein M, Keller SE (1986): Behavioral and developmental aspects of immunity. J Am Acad Child Psychiatry 26:751-763.

Schleifer Sj, Keller SE, Bond RN, Cohen J, Stein M (1989): Major depressive disorder and immunity. Arch Gen Psychia:?ry 46:81-87. 